\title{
Timed Artificial Insemination: Pregnancy Rates in Sokoto Gudali Cattle Treated with Prostaglandin F 2 Alpha at a Private Dairy Farm in Nigeria
}

\author{
Leigh Oluwadamilare Olufisayo, Mustapha Lukman, Agbugba Linda Chinyere*) and \\ Ibiam Adaeze Ezenwanyi
}

Department of Theriogenology, Faculty of Veterinary Medicine, University of Ibadan, Ibadan, Nigeria. *Corresponding author email: lindaagbugba@gmail.com

\begin{abstract}
Pregnancy rates (PR) resulting from timed artificial insemination (TAI) with frozen semen were investigated in 192 Sokoto Gudali (SG) cattle following estrus synchronization under 11- and 12- day treatment intervals with prostaglandin $\mathrm{F}_{2}$ alpha (Estrumate ${ }^{\circ}$ ). Two-point inseminations at $60 \mathrm{~h}$ and $72 \mathrm{~h}$ post Estrumate ${ }^{\circ}$ treatments were used. All cattle were randomly allocated to 2 groups i.e. $A$ and $B$, such that each sub-group of A1, A2, B1 and B2 had sixteen (16) cows and thirty two (32) heifers. Furthermore, cattle in Groups A and B were administered double Estrumate injections at 11 - and 12 -day intervals, respectively. Cattle in sub-groups $\mathrm{A} 1$ and $\mathrm{B} 1$ were inseminated at $60 \mathrm{~h}$ post second Estrumate injection while $\mathrm{A} 2$ and $\mathrm{B} 2$ were inseminated at 72 h. Pregnancy was diagnosed using the 60-day non return to estrus and confirmed via rectal palpation at 90 days post insemination. The results showed the following PR: $33 \%, 83 \%, 33 \%$ and $33 \%$ for cattle in sub-groups $\mathrm{A} 1, \mathrm{~A} 2, \mathrm{~B} 1$ and $\mathrm{B} 2$, respectively. It is concluded therefore that timed artificial insemination at $72 \mathrm{~h}$ in SG cattle treated with double Estrumate injections at 11-day interval produced the best pregnancy rate. These findings raises hope on the future application of TAI in breeding the SG cattle with prostaglandin $F_{2}$ alpha as single agent of estrus synchronization.
\end{abstract}

Keywords: Timed artificial insemination, estrus synchronization, prostaglandin $F_{2}$ alpha, pregnancy rates, Sokoto gudali cattle.

Abstrak. Penelitian dilakukan untuk menguji laju kebuntingan yang dihasilkan dari pengaturan waktu inseminasi buatan menggunakan semen beku pada 192 ekor sapi Sokoto Gudali setelah diberi perlakuan sinkronisasi estrus menggunakan prostaglandin $\mathrm{F}_{2}$ alpha (Estrumate ${ }^{\circ}$ ) dengan selang interval 11 dan 12 hari. Inseminasi dilakukan dua kali pada 60 jam dan 72 jam setelah perlakuan. Sapi diacak ke dalam 2 kelompok, yakni A dan B sehingga masing-masing sub grup A1, A2, B1 dan B2 memiliki 16 induk dan 32 dara. Sapi pada kelompok $A$ dan $B$ diberi dua kali injeksi menggunakan Estrumate ${ }^{(R)}$ dengan selang interval berturut-turut 11 dan 12 hari. Sapi pada sub grup A1 dan B1 diinsemiasi pada 60 jam setelah pemberian sedangkan kelompok A2 dan B2 pada 72 jam setelah pemberian Estrumate ${ }^{(R)}$. Diagnosa kebuntingan dilakukan menggunakan metode tidak munculnya estrus setelah 60 hari dan dikonfirmasi menggunakan palpasi rektal pada 90 hari setelah inseminasi. Hasil menunjukkan bahwa laju kebuntingan berturut-turut 33\%, 83\%, 33\% dan 33\% pada sapi di sub grup A1, A2, B1, dan B2. Dapat disimpulkan bahwa pengaturan waktu inseminasi pada 72 jam setelah sapi diberi suntikan Estrumate(R) pada selang interva 11 hari menghasilkan laju kebuntingan paling baik. Hasil ini memberikan harapan yang lebih baik untuk penerapan pengaturan waktu inseminasi pada program pembibitan sapi Sokoto Gudali menggunakan prostaglandin $\mathrm{F}_{2}$ alpha sebagai agen untuk melakukan sinkronisasi estrus.

Katakunci: Pengaturan waktu inseminasi buatan, sinkronisasi estrus, prostaglandin $F_{2}$ alpha, laju kebuntingan, sapi Sokoto Gudali

\section{Introduction}

Timed Artificial Insemination (TAl) programmes describe estrous synchronization protocols wherein estrus detection prior to insemination are not necessarily required. The success of TAI programmes depend much on the ability of the synchronization protocol/agent to achieve ovulation synchrony. At the present, many protocols, involving 
several agents, have been developed that perfectly fit into TAI. While some reports (Garcia and Salaheddine, 2001; Martinez et al., 2005) attest to the efficacy of Estradiol $17 ß$ in producing high degree of ovulation synchrony in heifers, Colazo and Mapletoft (2014) have described Estradiol-based TAI protocols as obsolete. Many other TAI-relevant protocols such as CoSynch, SelectSynch and Presynchronization are modifications of the OvSynch protocol that was first described by Pursley et al. (1995). The Ovsynch protocol is composed of a first gonadotropin (GnRH) injection on day zero ( $d 0$ ), followed by prostaglandin $\mathrm{F}_{2}$ alpha (d 7) and a second $\mathrm{GnRH}$ (d 9), after which cows are covered with semen between 8-18 hours thereafter (Pursley et al., 1997). The advantages of Ovsynch and its modifications include high submission and pregnancy rates (PR) in cows as well as overall improvement in reproductive performance (ElZarkouny et al., 2004; Pursley et al., 1997). Prostaglandin $F_{2}$ alpha (PGF) is involved in nearly all TAI protocols mentioned above. It functions to regress the corpus lutem (CL)(Day and Geary, 2005; Giordano et al., 2013), the source of progesterone, and thus, removing its inhibitory effects on the hypothalamo-pituitary axis. Subsequently, endogeneous GnRH is released for the regulation of the estrous cycle. An interesting fact is that PGF e.g. Estrumate is a single agent capable of synchronizing estrus. Its effectiveness have been shown in caprine (Leigh et al., 2010), bovine (Venkata et al., 2013), ovine (Omontese et al., 2014) and lately swine (Alimi et al., 2017). Few of PGF limitations however are its inability to regulate follicular waves (Mihm and Bleach, 2003), leading to poor ovulation synchrony, cows and heifers without a sensitive $\mathrm{CL}$ are also not responsive (Kastelic et al., 1990). The CL following recent ovulation (0-4 days) is refractory to PGF, while 5-16 $d$ post ovulation is senstive and by $17-21 d$ is already regressing (Wenzinger and Bleul, 2012). These variability results in wide variations in responses of cows and heifers to PGF treatment and hence poor PR, especially with the protocol involving single injection. The protocol involving double injections $10-14$ days apart produces better result compared to the earlier, and depending on considerations of cost of hormone and labour involved, either options may be favoured. Some researchers have carried out trials with single and double PGFinjection protocol for prediction of best time for insemination. One study reported $61.4 \%, 45.7 \%$ and $46.9 \%$ PR to TAl at 72 and 96 hrs (h) post single PGF treatment in zebu cows at three different farms (Rekwot et al., 1999), while another (Voh Jr. et al., 2000) reported 54.3\%, $45.7 \%, 41.4 \%$ and $40.0 \%$ to TAl at $60,72,84$ and $96 \mathrm{~h}$ post second PGF treatments, respectively. That two fixed-time inseminations at 72 and 96 $h$ were carried out (Rekwot et al., 1999) presupposes that PR ought to be higher than where single insemination was done at either period in agreement with the findings of Helmuth et al. (2005). Also, that PR at $60 \mathrm{~h}$ was better than at later hours (Voh Jr. et al., 2000) would alert inseminators that though peak estrus response occurs 2-3 days following PGF treatment, about $12 \mathrm{~h}$ to the end of that 'window' could be the optimum time to obtain highest PR. Since the Sokoto Gudali (SG) cattle continues to occupy a critical position in the Nigerian economy, where also PGF is the most accessible estrus synchronization agent, these claims require more investigation in order to ascertain the optimum insemination time. This study therefore investigated PR in SG cattle subjected to two-point insemination at 60 and $72 \mathrm{~h}$ following 11- and 12-day treatment intervals with Estrumate ${ }^{\circ}$.

\section{Materials and Methods}

Study site: The study was carried out at a private-owned dairy station established about eight years ago and located in the Ibarapa zone, Oyo State, Nigeria. The station houses a little 
over 500 cattle heads (all females) of the Bokolooji (Sokoto Gudali) breed.

Study animals and management: One hundred and ninety two (192) Sokoto Gudali cattle consisting of 64 cows (1-3 parity, 50-60 days post calving) and 128 heifers (175-240 kg) were used for the study. The animals spent most of their time in their pen where they were fed with silage and crushed elephant grass. They were allowed to graze in fenced paddocks for 35 hours daily during which their pens were cleaned.

Study design: The animals were randomly allocated to sub-groups A1, A2, B1 and B2 such that each group comprised of sixteen (16) cows and thirty two (32) heifers. The double PGF protocol was used for estrus synchronization. Animals in $\mathrm{A} 1$ and $\mathrm{A} 2$ were administered $(\mathrm{i} / \mathrm{m})$ $500 \mu \mathrm{g}$ Estrumate (Schering-Plough Animal Health Corp, Germany) at 11 days interval while those in B1 and B2 were administered same doses at 12 days interval. Insemination was carried out by a single experienced inseminator via the recto-cervical/vaginal method ( $A B S$, $2008)$, using thawed $\left(36^{\circ} \mathrm{C}\right)$ frozen semen from Holstein-Friesian bulls packaged in straws which were previously stored at $-196^{\circ} \mathrm{C}$. The semen straws were obtained from the International Fertilization Develpment Center (IFDC). Animals in $A 1$ and $B 1$ were inseminated at $60 \mathrm{~h}$ post second Estrumate ${ }^{\circ}$ injection while those in $A 2$ and B2 were similarly inseminated at $72 \mathrm{~h}$. The 60-day non return to estrus (Nematolla et al., 2013), was used to investigate cows that were pregnant. Pregnancies were thereafter confirmed through rectal palpation of the fetus at $d 90$ post insemination (Leigh, 2018).

Data Collection and Analysis: The pregnancy rate $(P R)$ was calculated by dividing the number of animals confirmed pregnant via rectal palpation by the number of animals inseminated in the sub-groups (Nematolla et al., 2013). Data were summarized using descriptive statistics (Elston and Johnson, 2008).

Guide on Research Conduct: The study was conducted under strict adherence to the principles of the care and use of farm animals in research, teaching and testing of the Canadian Council on Animal Use.

\section{Results and Discussion}

The results are shown in Tables 1 and 2 . Table 1 shows that under 11-day PGF treatment interval, the pregnancy rates (PR) of 33\% and $83 \%$ were obtained for sokoto Gudali (SG) cattle inseminated at $60 \mathrm{~h}$ (A1) and $72 \mathrm{~h}$ (A2) post double PGF injections, respectively. Table 2 similarly shows that under 12-day PGF treatment interval, the PR of $33 \%$ were obtained for SG cattle inseminated both at $60 \mathrm{~h}$ (B1) and $72 \mathrm{~h}$ (B2) post double PGF injections.

Table 1. Pregnancy rate of animals in group A treated with double PGF (Estrumate ${ }^{\circledR}$ ) injections at 11 days interval.

\begin{tabular}{cccc}
\hline Group (s) & $\begin{array}{c}\text { No. of } \\
\text { Animals }\end{array}$ & $\begin{array}{c}\text { Time of Insemination Post } \\
\text { PGF Injection }\end{array}$ & $\begin{array}{c}\text { Pregnancy } \\
\text { Rate }\end{array}$ \\
\hline A1 & 48 & $60 \mathrm{~h}$ & $33 \%$ \\
A2 & 48 & $72 \mathrm{~h}$ & $83 \%$ \\
\hline
\end{tabular}

Table 2. Pregnancy rate of animals in group B treated with double PGF (Estrumate ${ }^{\circledR}$ ) injections at 12 days interval.

\begin{tabular}{cccc}
\hline Group (s) & $\begin{array}{c}\text { No. of } \\
\text { Animals }\end{array}$ & $\begin{array}{c}\text { Time of Insemination } \\
\text { Post PGF Injection }\end{array}$ & $\begin{array}{c}\text { Pregnancy } \\
\text { Rate }\end{array}$ \\
\hline B1 & 48 & $60 \mathrm{~h}$ & $33 \%$ \\
B2 & 48 & $72 \mathrm{~h}$ & $33 \%$ \\
\hline
\end{tabular}


Our results clearly indicate that a singletimed artificial insemination at $72 \mathrm{~h}$ following prostaglandin-PGF (Estrumate ${ }^{\circ}$ ) synchronization in a double injection protocol of 11 days interval gave the highest pregnancy rate (PR). In this study, the PR for Sokoto Gudali (SG) cattle in other groups i.e. 11-day PGF interval $60 \mathrm{~h}$ insemination, as well as $60 \mathrm{~h}$ and $72 \mathrm{~h}$ inseminations under 12-day PGF interval were same and ridiculously low compared to that at $72 \mathrm{~h}$ 11-day interval. It is not unlikely that the low PR in these sub-groups could have arisen from several other factors, not excluding poor synchronization rate. These results suggest that for SG cattle, best PR may be obtained with double injections of Estrumate given at 11-day interval with insemination carried out at $72 \mathrm{~h}$ post treatment. The present finding is not in total agreement with the report of a study conducted in northern Nigeria which found that $60 \mathrm{~h}$ after two injections of PGF at 11 days interval was the optimum time for insemination in the White Fulani cattle (Voh Jr. et al., 2000). Although, that study agreed with the present one in terms of treatment interval of 11 days, it disagreed only on the time of insemination. The position of these authors cannot be contested at this level but it will suffice to reiterate that the present study recorded only 33\% PR under conditions that the earlier report claimed was best. The present study also shows that insemination around the end of the window for peak estrus response following PGF (Estrumate ${ }^{\circ}$ ) treatment, and not $12 \mathrm{~h}$ earlier yielded highest PR. While the present authors opined that many factors such as fertility of semen and inseminator efficiency could be responsible for this disparity, it is hoped that breed factor as earlier reported by Mai et al. (2014), did not play a role in the differences observed. In a similar study, Voh Jr. (1996) reported a PR of $74.1 \%$ in control cattle that were inseminated $12 \mathrm{~h}$ after detected estrus. Our current finding of $83 \%$ PR is undoubtedly better than $74.1 \%$, suggesting an advantage in terms of efficiency of PGF synchronization over spontaneous estrus, this is aside the rigours and failures associated with estrus detection. The current findings also appeared to be in consonance, though with a caveat, with the report that in heifers, single insemination at 72 $\mathrm{h}$ or $80 \mathrm{~h}$ after treatment with PGF gives normal fertility compared with insemination at $48 \mathrm{~h}$ or $60 \mathrm{~h}$ (Roch, 1977). Our finding with PR at $72 \mathrm{~h}$ insemination in the 11-day treatment interval group is in line with this report, albeit, cattle in group B2 had low PR. This observation may further strengthen the importance of PGF treatment interval in cattle synchronization programmes in that a little difference in treatment interval may result in huge losses with regards to $P R$ as shown in this study with group B2. The present finding of $83 \%$ PR is also suggestive of an improvement over two-fixed time inseminations at 60 and $72 \mathrm{~h}$ following a single administration of PGF in which the highest PR obtained in three farms was $61.4 \%$ (Rekwot et al., 1999). Although, It has not been clearly ascertained if double inseminations really has better chances of producing pregnancies more than single inseminations. While some authors (Helmuth et al., 2005) suspected it does, others (Stevenson et al., 1990) have found no benefit in double, over single inseminations. Our findings in the present study has however shown that single insemination at $72 \mathrm{~h}$ post PGF in an 11-day treatment interval has produced a very high pregnancy rate of $83 \%$ in Sokoto Gudali cattle. This result is better than previous ones reported and therefore suggest that the present protocol has the potential to increase the reproductive efficiency of cattle at breeding stations.

\section{Conclusions}

It is concluded therefore that timed artificial insemination at $72 \mathrm{~h}$ following double prostaglandin (Estrumate ${ }^{\circ}$ ) injections at 11-day treatment interval produced the highest pregnancy rate in Sokoto Gudali cattle. 


\section{Acknowledgements}

The authors gratefully appreciate the cooperation of the Management of SUMAP Farms Plc, Ibarapa, Oyo State, Nigeria, for providing the animals used, and Mr. Zaillani of the International Fertilization Development Centre, who provided frozen semen.

\section{References}

Alimi YA, OO Leigh, OO Ajala and JO Abiola. 2017. Estrus responses and hormonal profiles of gilts following treatments with prostaglandin $F 2 \alpha$. Mac. Vet. Rev. 40(1): 13-20.

ABS (American Breeding Society). 2008. Artificial Insemination Manual. $6^{\text {th }}$ ed. ABS Global Inc., Wisconsin.

Colazo MG and RJ Mapletoft. 2014. A review of current timed-Al (TAI) programs for beef and dairy cattle. Can. Vet. J. 55(8): 772-780.

Elston RC, and WD Johnson. 2008. Basic Biostatistics for Geneticists and Epidemiologists. A Practical Approach, $1^{\text {st }}$ ed. John Willey and Sons Ltd, UK

El-Zarkouny SZ, JA Cartmill, BA Hensley, and JS Stevenson. 2004. Presynchronization of estrous cycles before Ovsynch and progesterone in dairy cows: Ovulation, pregnancy rates, and embryo survival. J. Dairy Sci. 87: 1024-1037.

Garcia A and M Salaheddin M. 2001. Effect of oestrous synchronization with Estradiol 17 ß and progesterone on follicular wave dynamics in dairy heifers. Reprod. Dom. Anim. 36: 301-307.

Day ML and TW Geary. 2005. Handbook of estrous synchronization. Western Region Publication No .014. Ohio Agricultural Research and Development Center, The Ohio State University. 41 pages.

Giordano JO, MC Wiltbank, PM Fricke, S Bas, R Pawlisch, JN Guenther and AB Nascimento. 2013. Effect of increasing GnRH and PGF2alpha dose during DoubleOvsynch on ovulatory response, luteal regression, and fertility of lactating dairy cows. Theriogenology 80, 773-783.

Helmuth KJ, KA Ringwall and G Ottmar. 2005. Artificial insemination of postpartum beef cows utilizing single insemination Vs. Double insemination- Preliminary Observations. North Dakota State University- Dickinson Research Extension Center.

Kastelic JP, L Knopf and OJ Ginther. 1990. Effect of day of prostaglandin treatment on selection and development of the ovulatory follicle in heifers. Anim. Reprod. Sci. 23: 169-180.
Leigh OO. 2018. Rectal palpation for pregnancy diagnosis in the cow/heifer, In: Handbook of Bovine Rectal Palpation with Notes on the Mare for Veterinary Students. OO Leigh (Ed). Shirling Horden Publishers Ltd. Nigeria, Pp: 59-66.

Leigh OO, AK Raheem and OJA Oluwadamilare. 2010. Improving the reproductive efficiency of the goat: Vaginal cytology and vulvar biometry as predictors of synchronized estrus/breeding time in West African dwarf goat. Int. J. Morphol. 28(3): 923-928.

Mai HM, AA Voh and PS Deshi. 2014. Some fertility indices in an artificially inseminated Bunaji and Bokoloji herds in Kaduna State, Nigeria. Global Vet. 12(2): 171-175.

Martinez MF, JP Kastelic, GA Bo, M Caccia and RI Mapletoft. 2005. Effects of oestradiol and some of its esters on gonadotropin release and ovarian follicular dynamics in CIDR-treated beef cattle. Anim. Reprod. Sci. 86: 37-52.

Mihm M and EC Bleach. 2003. Endocrine regulation of ovarian antral follicle development in cattle. Anim. Reprod. Sci. 78: 217-237.

Nematollah D, k Keyvan and B Hasan. 2013. Reproductive performance definition in dairy cattle: affective factors. IJABBR. 1(11): 13921396.

Omontese BO, PI Rekwot, JS Rwuaan, IU Ate and HJ Makun. 2014. Induction of oestrus in Nigerian Ouda ewes with different oestrus synchrony protocols. Rev. Méd. Vét. 165(7-8): 240-244.

Pursley JR, MO Mee and MC Wiltbank. 1995. Synchronization of ovulation in dairy cows using $\mathrm{PGF}_{2 \alpha}$ and GnRH. Theriogenology. 44: 915-923.

Pursley JR, MC Wiltbank, JS Stevenson, JS Ottobre, HA Garverick, and LL Anderson. 1997. Pregnancy rates per artificial insemination for cows and heifers inseminated at a synchronized ovulation or synchronized estrus. J. Dairy Sci. 80: 295-306.

Rekwot PI, EO Oyedipe, E Mukasa-Mugerwa, VO Sekoni, OP Akinpelumi and AA Anyam. 1999. Fertility in zebu cattle (bos indicus) after prostaglandin administration and artificial insemination. Vet. J. 158: 53-58.

Roch JF. 1977. Synchronization of estrus with prostaglandin. Vet. Sci. Comm. 1: 121-129.

Stevenson JS, EP Call, RK Scorby and DP Phatak. 1990. Double insemination and GnRH treatment of repeat breeding dairy cattle. J. Dairy Sci. 73(7): 1766-72.

Venkata RK, KS Rao, K Supriya and N Rajanna. 2013. Effect of prostaglandin on estrus response and conception rate in lactating ongole cow. Vet. World. 6(7): 413-415.

Voh Jr AA, D Ogwu and EO Oyedipe. 2000. Determination of optimum fixed time artificial insemination of zebu cows following 
synchronization of estrus with prostaglandin F2 alpha. Nig. Vet. J. 21: 38-50.

Voh Jr AA. 1996. Fertility and embryonic mortality rates of zebu cows following oestrus synchronization and artificial insemination.
Thesis. The Post Graduate School, Ahmadu Bello University, Zaira.

Wenzinger B and $U$ Bleul. 2012. Effect of a prostaglandin F2 alpha analogue on the cyclic corpus luteum during its refractory period in cows. BMC Vet. Res. 8: 220. 